\title{
DESCRIPTION OF A NEW WATER MITE SPECIES OF THE GENUS PIONA KOCH (ACARI, HYDRACHNIDIA, PIONIDAE) FROM NORTHEASTERN RUSSIA
}

\author{
Petr V. Tuzovsky \\ Institute for Biology of Inland Waters, Russian Academy of Sciences, Borok, \\ Yaroslavl Prov., Russia \\ E-mail: tuz@ibiw.yaroslavl.ru
}

ABSRACT. A description of a new water mite species Piona from standing waters of the Kamchatka and Chukotka is given.

KEY WORDS: Pionidae, Piona simulans, water mite, new species, male, female, deutonymph, larva, morphology.

DOI: $10.21684 / 0132-8077.2016 .24 .1 .41 .50$

\section{INTRODUCTION}

The aim of this paper is to describe the female, male, deutonymph, and larva of a new water mite species of the genus Piona Koch, 1842.

The following abbreviations are used: P-1-5, pedipalp segments (trochanter, femur, genu, tibia and tarsus); I-Leg. 1-6, first leg, segments 1-6 (trochanter, basifemur, telofemur, genu, tibia, and tarsus) i.e. III-Leg-4 - genu of third leg; ac. 1-2genital acetabula (median and lateral); L-length; $\mathrm{W}$-width; $\mathrm{D}$ - diameter; $\mathrm{n}=$ number of specimens measured. The length of appendage segments was measured along their dorsal side; all measurements are given in micrometers $(\mu \mathrm{m})$.

\section{DESCRIPTIONS}

\section{Piona simulans Tuzovskij sp.n.}

Figs 1-27

Type material. Holotype: female, slide 4646, Russia, Kamchatka Province, Ust-Kamchatsk Distr., Dyakonovskoe lake, 5.07.1983, leg. P. V. Tuzovsky. Paratypes: 1 female same data as holotype, 1 male and two females 2.09.1983 same locality as holotype, 1 female from Azabachye lake, 1.07.1983. Additional material: Russia, Magadan Province, Chukotka, Anadyr Distr., small lake near settlement Markovo, 2 females, 1 male, and 4 deutonymphs, 29.07.1981,2 males and 1 deutonymph 30.07.1981, leg. P. V. Tuzovsky. The holotype is deposited in the collection of Institute for Biology of Inland Waters, RAS (Borok, Russia).

Female. Idiosoma oval, integument soft and finely striated. Dorsum with small elongated platelets, ratio L/W 2.5-2.7 (Fig. 1). The number and position of idiosomal setae typical for the genus Piona. All dorsal setae thin and approximately equal in length, but setae $F c h$ (Fig. 2) shorter and thicker than other idiosomal setae. Coxae of legs cover about half ventral surface (Fig. 3). Anterior coxal plates with short apodemes. Sclerites bearing setae $H v$ free and located between anterior and posterior coxal groups. Suture line between coxal plates III and IV complete. Medial margin of coxal plate IV twice longer than medial margin of coxal plate III. Posterior margins of coxal plates IV forming obtuse angle, apodemes moderately developed. Genital opening longer than acetabular plates, the latter wider rather than long, with straight or slightly concave medial margin and rounded laterally; 22-33 genital acetabula on each side, two pairs of which larger than others. Acetabula situated mainly on periphery of plates. Anterior large acetabulum located slightly laterally to anteromedial corner of acetabular plate, second large acetabulum located a little posterior to middle of the plate. All acetabula and three to four pairs of genital setae located on the plates, one seta located anteromedially and two to three genital setae located posteromedially on each side; in addition, two (occasionally three) pairs of genital setae located in integument between acetabular plates and pregenital sclerite. Excretory pore surrounded by sclerotized ring.

Chelicera (Fig. 4) with large basal segment and short crescent chela. Pedipalp rather slender (Fig. 5): $\mathrm{P}-1$ with a single short dorsodistal seta; $\mathrm{P}-2$ large, with slightly convex ventral margin and bearing seven to eight dorsal setae; P-3 with three short subequal setae, bases of all setae located distally to middle of segment; P-4 and P-2 subequal in length; $\mathrm{P}-4$ proximoventral seta located on small subequal tubercle, distoventral seta on relatively large tubercle, distoventral spine short located on tubercle, and with some smaller setal tubercles in distal half of segment; P-5 thin, with proximal solenidion, five thin setae and four thick distal spines.

Legs thin and slender. I-Leg-4 with 0-2, ILeg-5 with 2-4 short swimming setae (Fig. 6). Legs II-IV with long swimming setae, their number as 


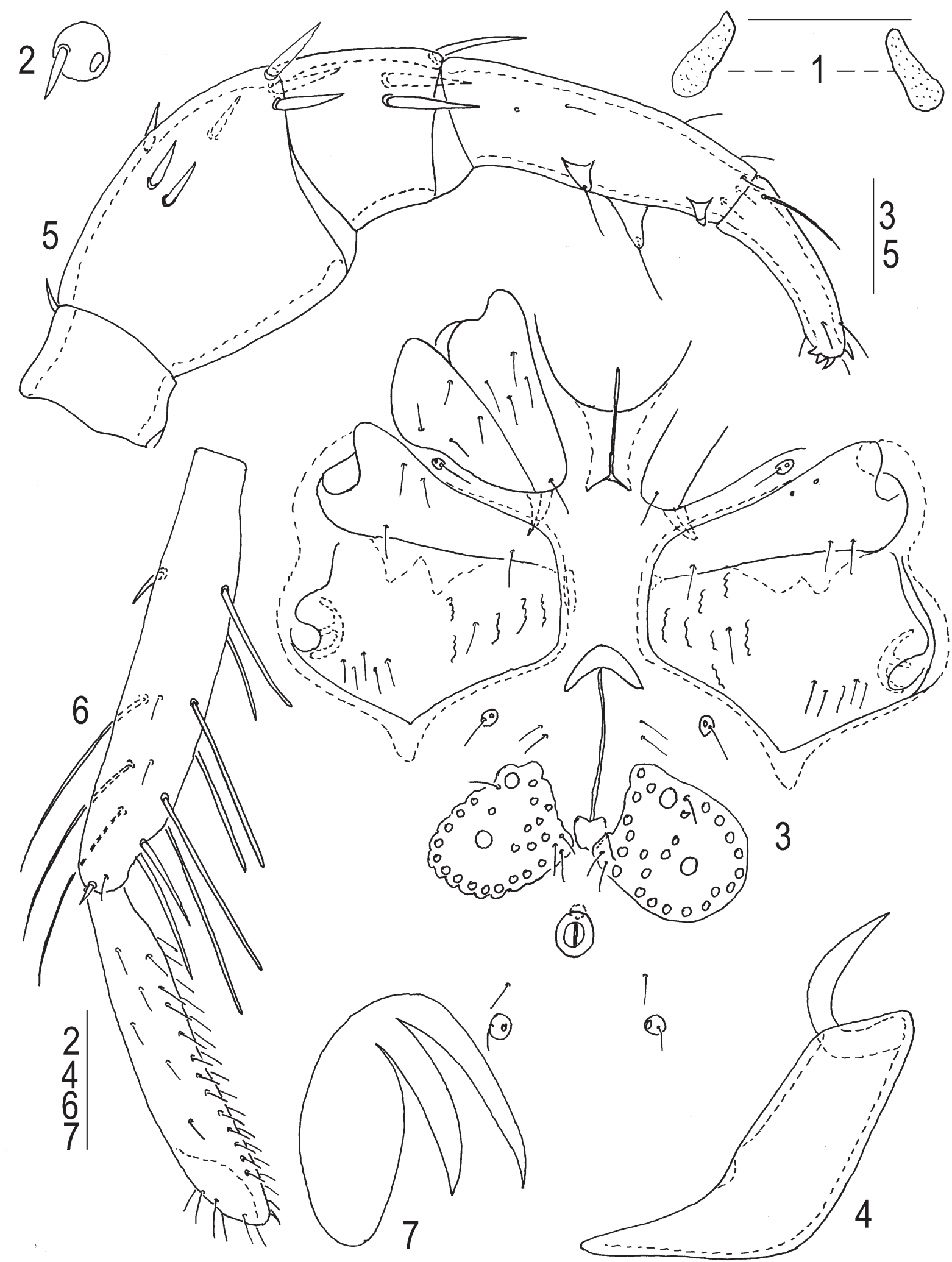

Figs 1-7. Piona simulans sp.n., female: 1 -dorsal plates; 2 - seta $F c h ; 3$ - coxal plates and genital field; 4 - chelicera, 5-pedipalp, lateral view; 6-I-Leg-5-6; 7—claw of leg II. Scale bars: 2, 4, 6,7 = $100 \mu \mathrm{m} ; 1,3,5=200 \mu \mathrm{m}$.

follows: 3-6 on II-Leg-4, 5-8 on II-Leg-5 and III/ IV-Leg-4, 8-11 on III-Leg-5, 10-12 on IV-Leg-5.
Claws with long external and short internal clawlets, lamella with convex ventral margin (Fig. 7). 


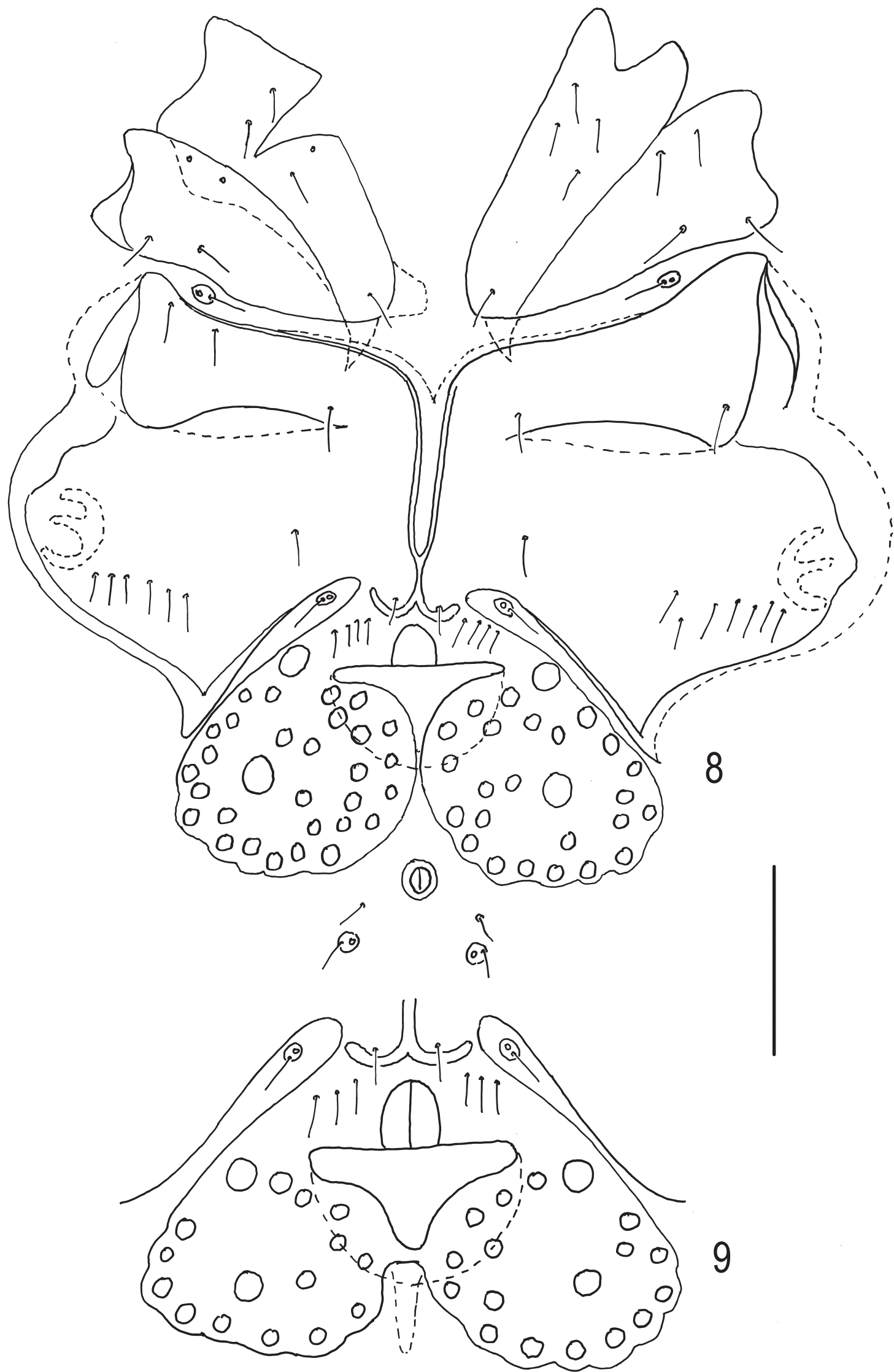

Figs 8-9. Piona simulans sp.n., male: 8—coxal plates and genital field; 9—genital field. Scale bar: $11=200 \mu \mathrm{m}$. 


\section{P. V. Tuzovsky}

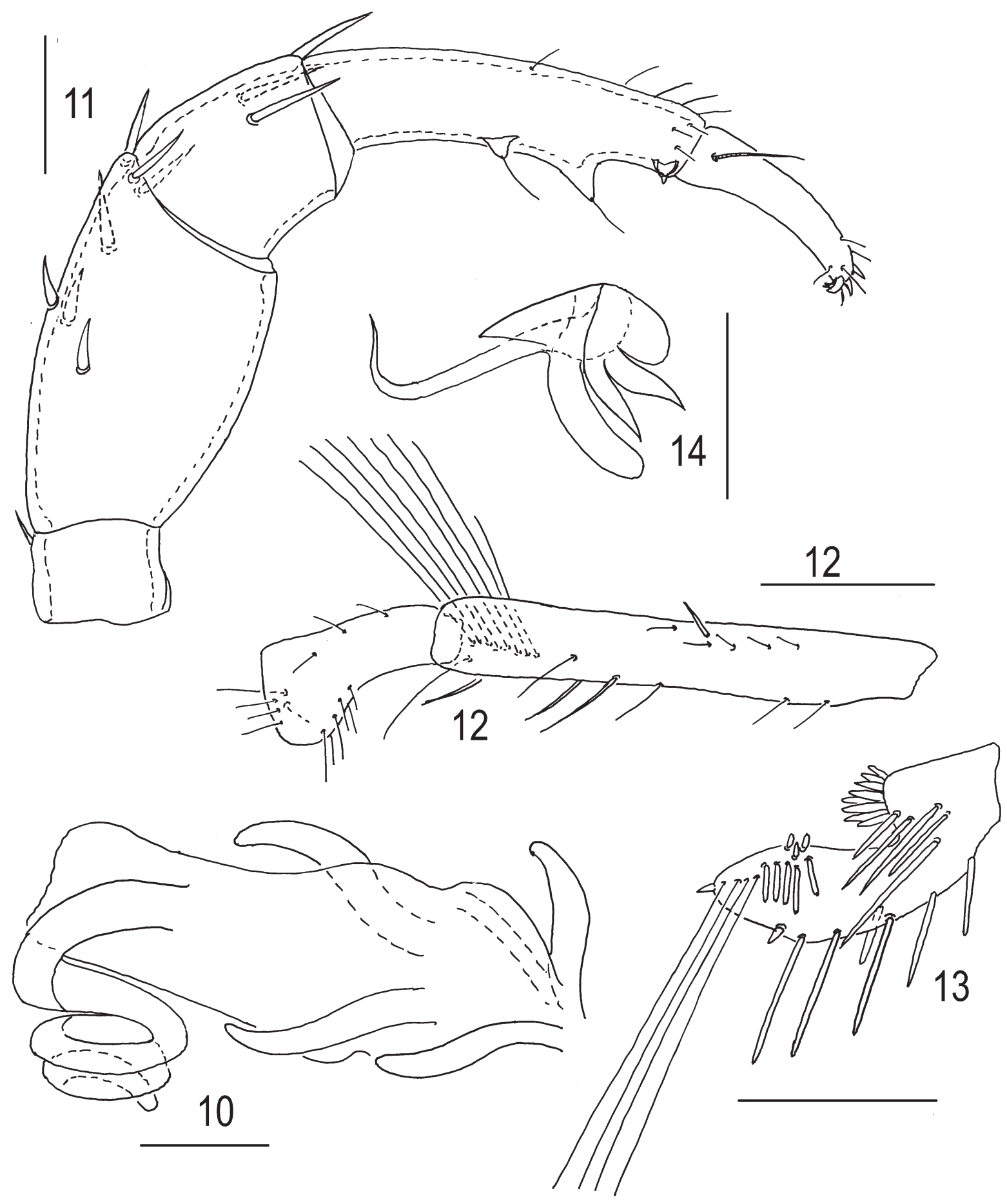

Figs 10-14. Piona simulans sp.n., male: 10 - ejaculatory complex; 11—pedipalp; 12-III-Leg-5-6; 13-IV-Leg- 4; 14 - claws of leg III. Scale bars: $10,14=50 \mu \mathrm{m} ; 11-100 \mu \mathrm{m} ; 12-13=200 \mu \mathrm{m}$.

Measurements, $\mathrm{n}=7$. Idiosoma L 935-1450; acetabular plates L 150-170, W 190-210; cheliceral segments: base L 290-300, chela L 108-120; medial edge of coxal plates III L 54-60, medial edge of coxal plates IV L 105-120; small acetabula D 12-18; large acetabula D 24-30; pedipalp segments (P-1-5) L: 54-60, 220-240, 108-120, 215-235, 125-145; leg segments L: I-Leg-1-6:
75-90, 135-150, 160-200, 255-290, 295-320, 265-285; II-Leg-1-6: 90-105, 150-165, 190-210, 285-320, 330-375, 275-300; III-Leg-1-6: 100110, 150-165, 190-210, 300-325, 350-390, 285-315; IV-Leg-1-6: 160-195,165-185, 235-255, 345-365, 390-420, 285-320.

Male. Dorsum similar those of the female. Anterior coxal plates with short apodemes, genital field 

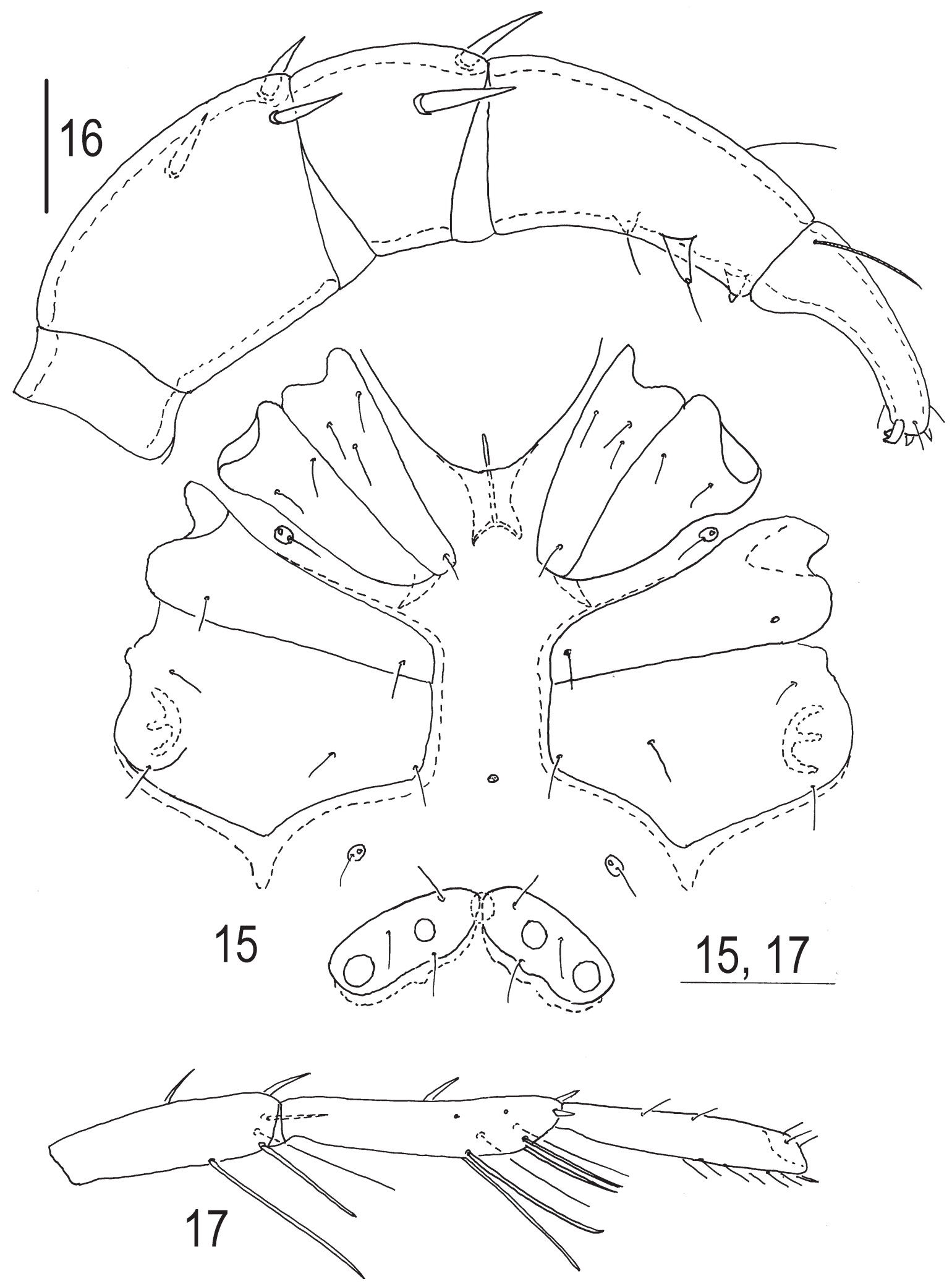

Figs 15-17. Piona simulans sp.n., deutonymph: 15-idiosoma, ventral view; 16-pedipalp; 17-I-Leg-4-6. Scale bars: $15,17=100 \mu \mathrm{m} ; 16=50 \mu \mathrm{m}$.

fused with fourth coxal plates (Fig. 8-9). Genital field reaching or slightly extending laterally beyond posterior corner of fourth coxal plates, with no deep genital pit; 15-30 genital acetabula on each side, two pairs of which larger than others. Genital opening trifoliate, with small anteromedian incision. Ejaculatory complex with subequal proximal and distal arms, proximal chamber large with a curving proximal projection 

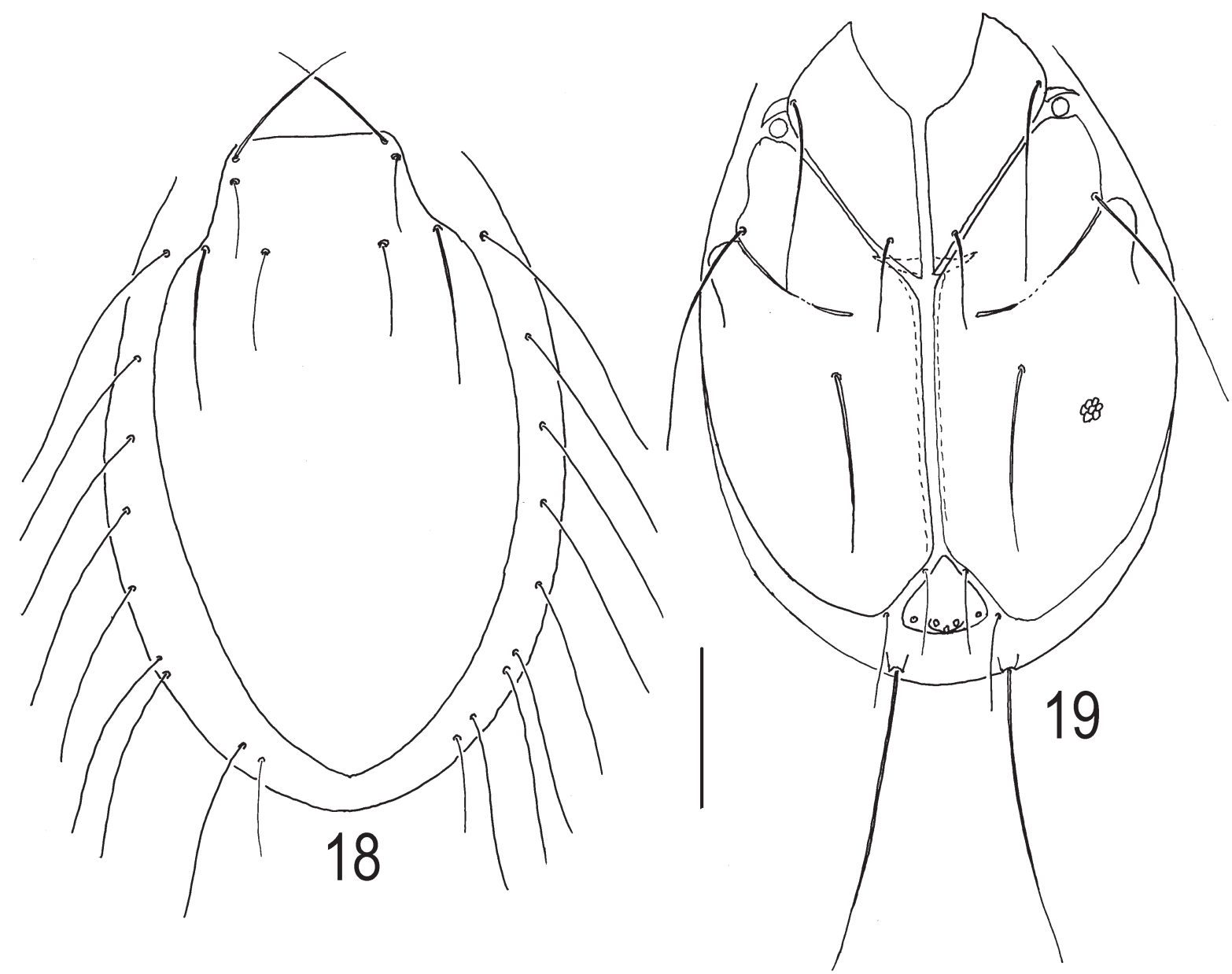

Figs 18-19. Piona simulans sp.n., larva: 18—dorsal view; 19—ventral view. Scale bar: $100 \mu \mathrm{m}$.

forming three coins (Fig. 10). Excretory pore surrounded by narrow sclerotized ring.

Pedipalp rather slender (Fig. 11): P-1 with single short dorsodistal seta; P-2 with 7 short setae; P-3 with 3 short subequal setae, lateral seta located near middle of segment, P-4 proximoventral setae located on small subequal tubercle, distoventral seta on relatively large tubercle, distoventral spine short located on tubercle, proximoventral seta and distoventral seta well separated.

I-Leg-5-6 and II-Leg-5-6 not expanded towards distal end. III-Leg-5 long, straight, III-Leg-6 short and club-shaped (Fig. 12); IV-Leg-4 thick and has a deep concavity bearing numerous unequal spine-like setae (Fig.13). I-Leg-4 with 0-1, I-Leg-5 with 3-5 short swimming setae. Legs II-IV with long swimming setae, their number as follows: 4-7 on II-Leg-4, 5-8 on II-Leg-4, 9-12 on III-Leg-5; 4-5 on IV-Leg-4, 7-11 on IV-Leg-5. Claws of legs III asymmetric (Fig. 14); large claw with thick, long pointed dorsal clawlet and relatively short ventral one with rounded tip; small claw with short subequal pointed clawlets.
Measurements, $n=4$. Idiosoma L 900-1080; genital field W 345-360; cheliceral segments: base L 220-245, chela L 90-105; small acetabula D 12-20; large acetabula L 24-30; pedipalp segments (P-1-5) L: 48-55, 215-260, 114-125, 220-270, 120-135; leg segments L: I-Leg-1-6: 90-105, 135-170, 175-180, 240-270, 300-315, 245-265; II-Leg-1-6: 100-108, 150-156, 190-205, 230-285, 335-345, 255-300; III-Leg-1-6: 90-96, 130-145, 120-140, 220-230, 330-350, 125-145; IV-Leg-1-6: 160-170, 150-165, 144-50, 270-276, 340-365, 275-480.

Deutonymph. Similar to female, differing mainly in smaller size, external structure of genital field and number of setae on appendages. Coxal plates like those the female, but with smaller number of setae (Fig. 15). Acetabular plates fused to each other anteromedially and with genital sclerite, bearing two acetabula and three setae each. Median acetabulum usually lesser than lateral one, but sometimes subequal in size. Genital sclerite larger than pregenital sclerite.

Pedipalp stout (Fig. 16): P-1 short, without seta; P-2 large, with straight ventral margin and bearing 

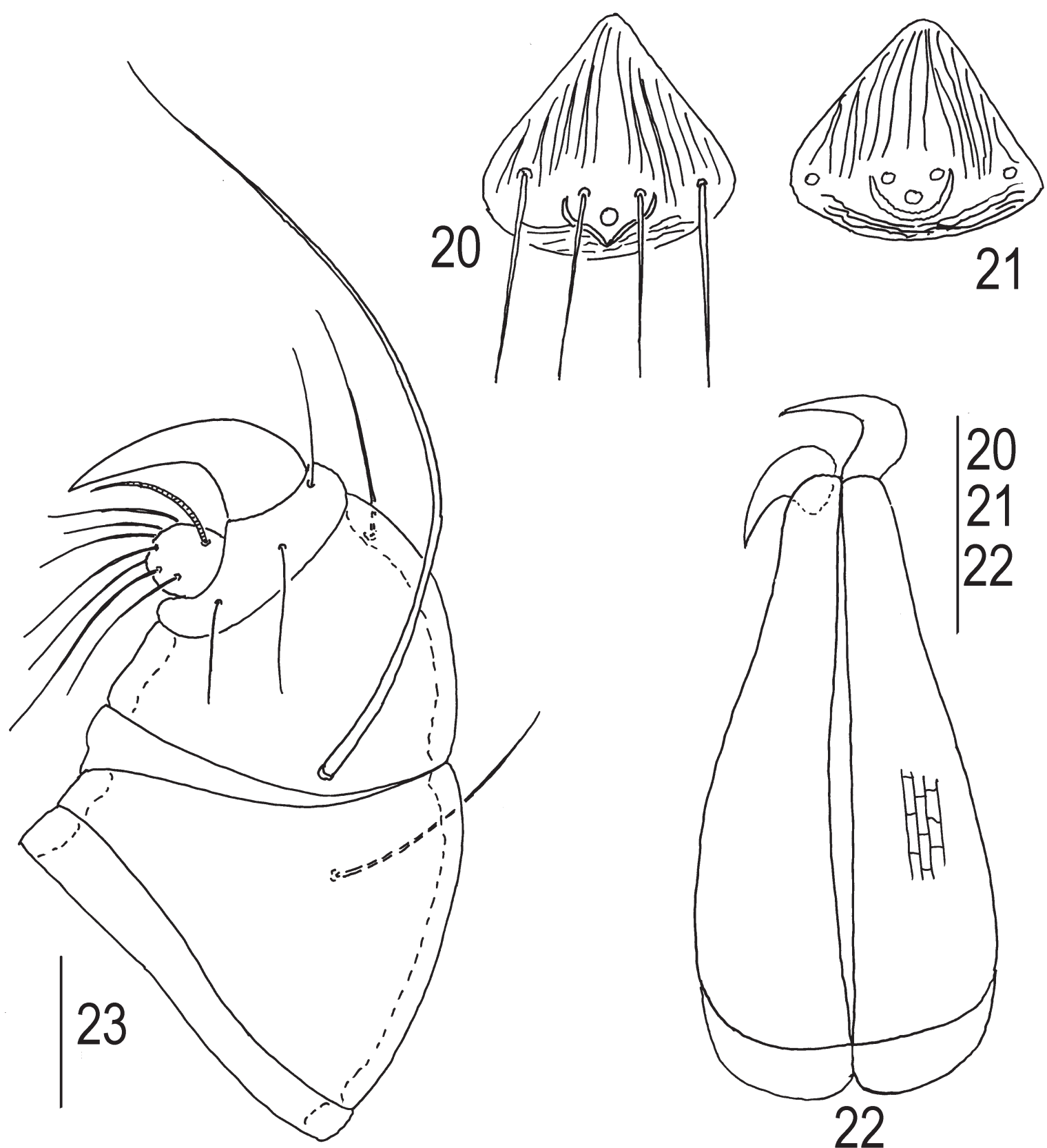

Figs 20-23. Piona simulans sp.n., larva: 20-21-excretory pore plate; 22—chelicerae, dorsal view; 23 -pedipalp, lateral view. Scale bars: $20-22=50 \mu \mathrm{m}, 23=100 \mu \mathrm{m}$.

three subequal dorsal setae; P-3 with two short unequal setae, base of lateral seta located distally to middle of segment; P-4 proximoventral setae located on small subequal tubercle, distoventral seta on relatively large tubercle, distoventral spine short located on tubercle, P-5 with proximal solenidion, three thin setae and four thick distal unequal spines.

Legs thin and slender. I-Leg-4 with one swimming seta, I-Leg-5 with two short swimming setae (Fig. 17). Legs II-IV with long swimming setae, their number as follows: $0-2$ on II-Leg-4, 2-3 on II-Leg-5, 4-5 on III-Leg-5, and 5-6 on IV-Leg-5.

Measurements, $\mu \mathrm{m}(\mathrm{n}=6)$. Idiosoma L 600 720; genital field L 54-60, W 160-170; medial edge of coxal plates III L 30-32, medial edge of coxal plates IV L 60-65, genital acetabula (ac.1ac.2) D 21-27, 27-30; cheliceral segments: base L 125-140, chela L 55-56; pedipalp segments (P-1-5) L: 24-27, 108-115, 63-66, 114-120, 78-85; leg segments L: I-Leg-1-6: 45-48, 65-72, 78-90, 114-120, 144-150, 138-145; II-Leg-1-6: 45-48, 
P. V. Tuzovsky

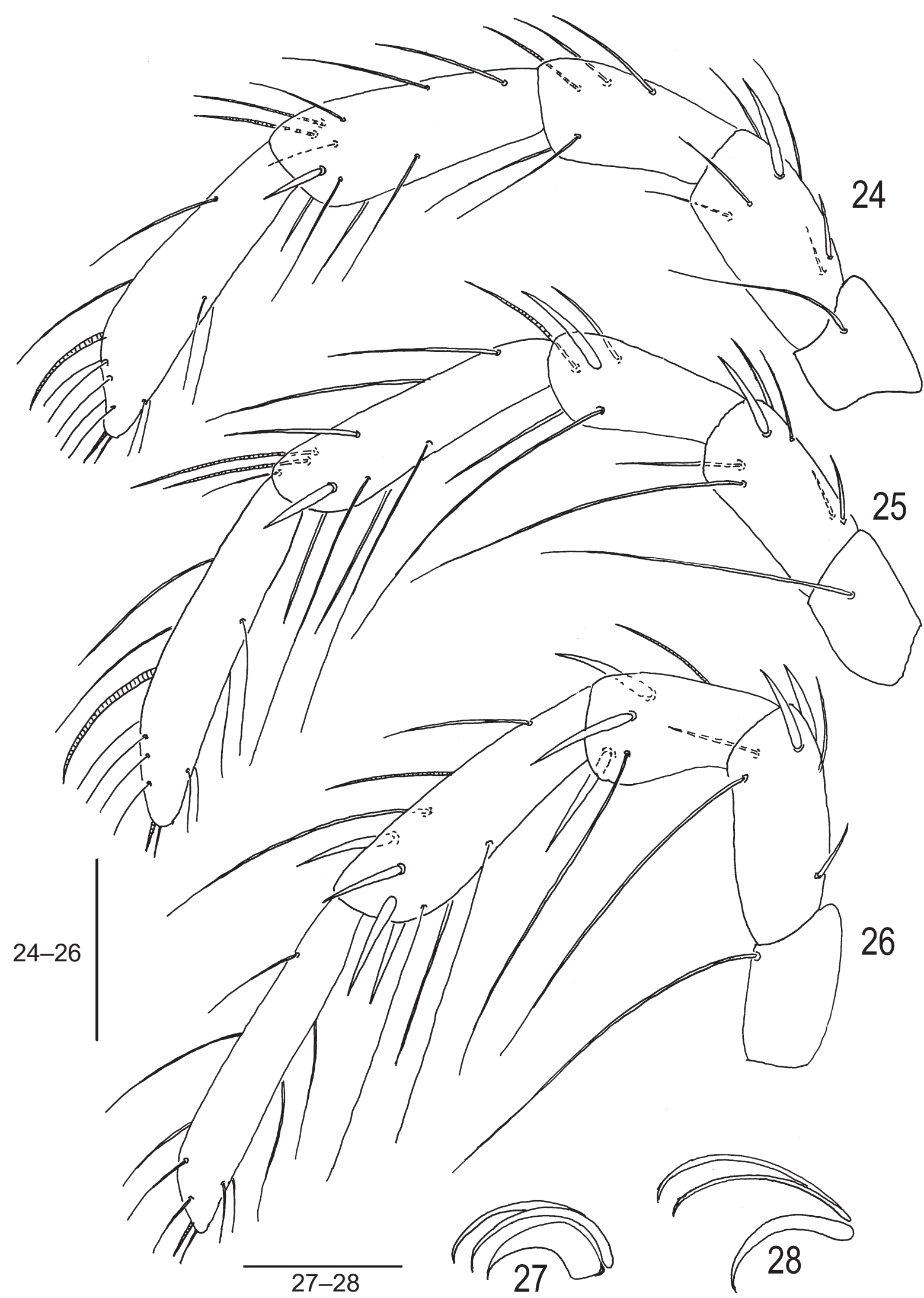

Figs 24-28. Piona simulans sp.n., larva: 24-leg I; 25-leg II; 26-leg III; 27—claws of leg I; 28—claws of leg III. Scale bars: $24-26=50 \mu \mathrm{m}, 27-28=20 \mu \mathrm{m}$. 


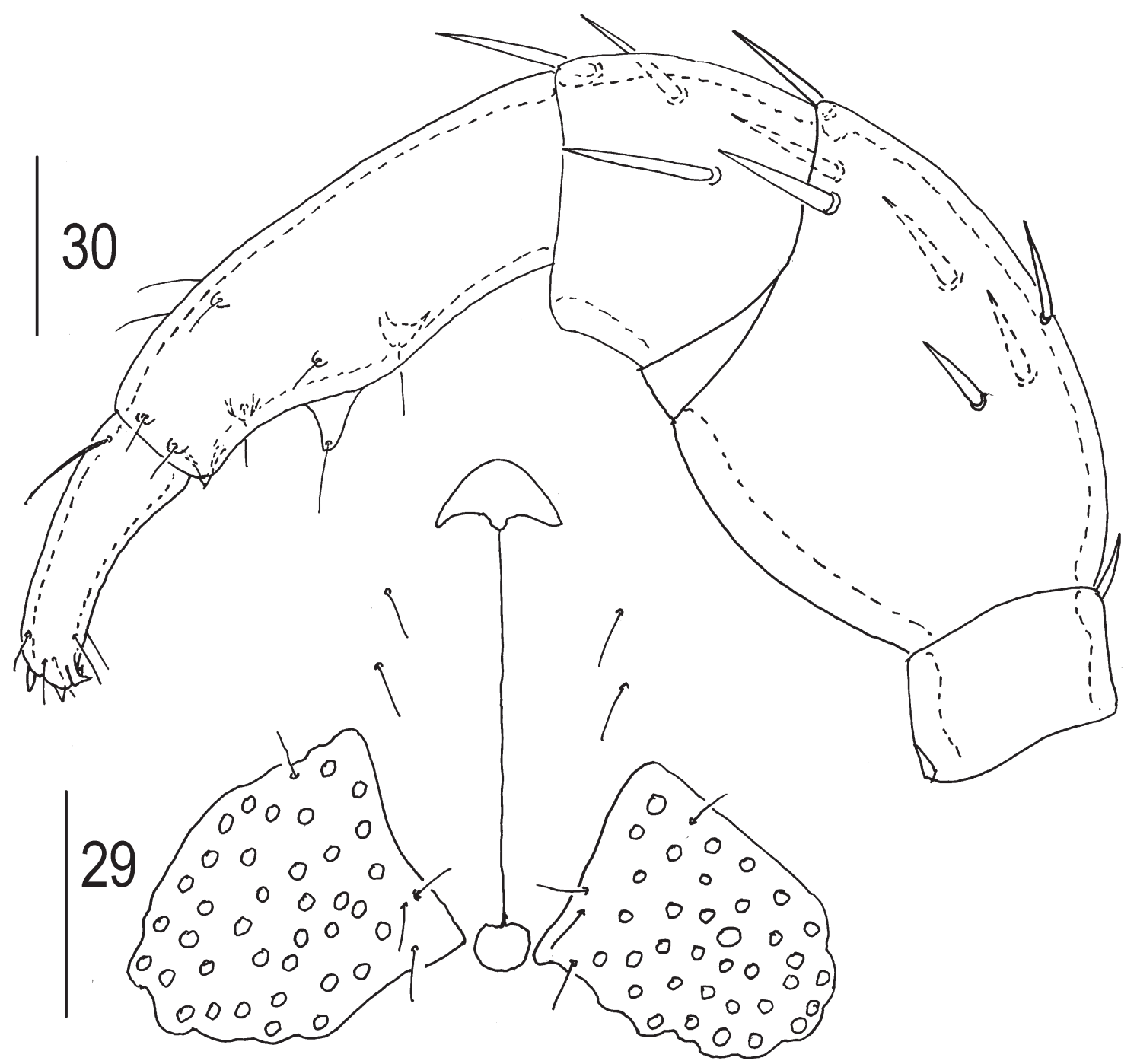

Figs 29-30. Piona stjoerdalensis (Thor, 1897), female (collected in Yaroslavl Province): 29—genital field, 30 -pedipalp. Scale bars: $29=200 \mu \mathrm{m}, 30=100 \mu \mathrm{m}$.

70-78, 85-90, 135-140, 174-180, 155-162; IIILeg-1-6: 50-55, 78-85, 84-87, 130-140, 185-192, 155-170; IV-Leg-1-6: 90-96, 84-95, 110-115, 160-170, 204-207, 162-168.

Larva. Idiosoma flat, dorsal plate elongate (L/W ratio 1.6-1.8), in unengorged larvae covering almost the whole dorsum (Fig. 18), with slightly convex lateral margins, its anterior margin straight or slightly convex, posterior margin rounded; setae $F c h$ shorter than $V i$, trichobothria $F p$ shorter than $\mathrm{Oi}$. Setae $\mathrm{Oe}, \mathrm{Hi}, \mathrm{He}, \mathrm{Sci}$, Sce, $\mathrm{Li}, \mathrm{Li}$, Si and $\mathrm{Se}$ situated in soft membrane, Oe longest, $S i$ shortest; $\mathrm{Hi}, \mathrm{He}, \mathrm{Sci}$, Sce and Le moderately in length.

Coxal plates (Fig. 19) moderately large and elongate, first plates with short pointed apodemes directed laterally, plates II-III without apodeme on each side. Seta $\mathrm{C} 1$ relatively short not reaching bases of $\mathrm{C} 4$; the latter setae relatively thick, not reaching posterior margin of coxal plates III, and slightly shorter than C3. Setae $C i$ very long thickened, located on small tubercles. Setae $P i$ and $P e$ moderate in length. Excretory pore plate (Figs 20-21) triangular (L/W ratio 1.0-1.05) with convex posterior margin; setae $A i$ and $A e$ subequal and forming true transverse row; bases of $A i$ close to each other, located anteriorly to excretory pore; distance between setae $A e-A e$ almost three times longer than distance between $A i-A i$. Surface of excretory pore plate with thin strips.

Basal segments of chelicerae (Fig. 22) fused to each other medially, longer than wide, expanded proximally and tapering distally; chela small, crescent-shaped.

Pedipalps short and stocky (Fig. 23): P-1 short and without seta; P-2 large with slightly convex dorsal margin, with single dorsolateral seta distally middle of segment; P-3 with very long, thick proximolateral seta and relatively short dorsodistal 
one; P-4 with three unequal thin setae and large dorsodistal claw; P-5 small, with single solenidion and seven unequal simple setae, solenidion longer than segment.

Legs 5-segmented, shape and arrangement of setae on legs segments as shown in Figs 24-26. Total number of leg setae, excluding eupathidia, as follows (specialized setae indicated in parentheses): I-Leg-1-5: 1, 7, 5 (s), 11 (2s), 14 (s, ac); II-Leg-1-5: 1, 7, 5 (s), 11 (2s), 13 (s, ac); III-Leg-1-5: 1, 6, 5 (s), 10, 11 (ac). Number of thickened distal setae from trochanter to tarsus: I-Leg: 0, 1, 0, 1, 0; II-Leg: 0, 1, 1, 1, 0; III-Leg: 0, 2, 3, 4, 0. I-Leg-1 with relatively short seta, II-Leg-1 and III-Leg-1 each with long seta. Solenidion on I-Leg-3 and II-Leg-3 located distally, solenidion on III-Leg-3 located near middle of segment; I-Leg-4 with subequal dorsodistal solenidia, II-Leg-4 with unequal dorsodistal solenidia. Acanthoid seta comparatively long and setose, located distally on tarsus of all legs. Lateral claws and empodial claw nearly equal in length, but lateral claws less heavy than empodial claw; empodial claw I-II well curved (Fig. 27), empodial claw III slightly curved (Fig. 28).

Measurements, $\mathrm{n}=10$. Dorsal plate L 288-318, W 175-185; setae Fch L 48-55, setae Fp L 25-29, seta $O i$ L 32-35; setae $V i$ L 55-60; setae L Oe 108115; setae Hi, He, Sci, Sce, Li, Le L 75-85; setae Si L 39-48; setae $S e$ L 73-80, setae $C i$ L 160-170, setae $P i$ L 48-52; setae $P e$ L 50-59, setae $A i$ L 41-45; setae $A e$ L 45-48; seta C1 L 55-58, setae C2 L 65-80, setae C3 L 90-112, setae C4 L 83-90; medial edge of coxa I L 75-85, medial edges of coxae II+III L 150-160; excretory pore plate L 44-52, W 48-52; cheliceral segments: base L 118-122, chela L 28-30; pedipalpal segments (P-1-5) L: 6-7, 41-45, 33-36, 7-8, 6-7; legs segments L: I-Leg-1-5: 35-39, 48-55, 54-58, 75-80, 83-87; II-Leg-1-5: 38-48, 51-61,
55-60, 83-90, 89-96; III-Leg-1-5: 47-50, 51-58, 57-61, 86-90, 105-110.

\section{DIFFERENTIAL DIAGNOSIS}

The present species is closely related to Piona stjoerdalensis (Thor, 1897) but differs in the following characters (character states of $P$. stjoerdalensis are indicated in parentheses): in the adults of $P$. simulans sp.n. genital acetabula situated mainly on periphery of plates, two pairs of which larger than others, Figs 3, 9 (on all surface of plates, all acetabula are similar in size, Fig. 29); P-4 with two large setal tubercles and without smaller setal tubercles (with some smaller setal tubercles, Fig. 30).

The excretory pore plate in the larva $P$. stjoerdalensis smooth, the small coxal apodemes II and III present, I-Leg-3 solenidion base situated distally (Tuzovskij 2016). In contrast, in the larva $P$. simulans the surface of the excretory pore plate with strips, the coxal apodemes II and III absent, I-Leg-3 solenidion base situated near middle of segment.

Habitat. Standing waters.

Distribution. Asia (Russia: Kamchatka and Chukotka).

\section{ACKNOWLEDGEMENTS}

The author expresses sincerely gratitude to anonymous referees for reviewing the manuscript.

\section{REFERENCES}

Tuzovskij, P.V. 1987. Morphology and Postembryonic Development of Water Mites. Moscow: Nauka. 172 pp. [In Russian].

Tuzovskij, P.V. 2016. Larval morphology of Piona stjoerdalensis (Thor, 1897) (Acari, Hydrachnidia: Pionidae). Ecologica Montenegrina, 5: $57-61$. 